\title{
The Beauty in Design - Aesthetics and Functions Caused by Combining Analogue with Digital Processing - Case Studies of Fashion Engineering and Automotive Design
}

\author{
Wachs $M E^{1 *}$, Bendt $E^{2}$, Kreuziger $M^{1}$, Brinkmann $T^{1}$, Dornbusch $L^{1}$, Scholl $T^{1}$, Krinner $S^{1}$, Detering $N^{1}$ and Pfanzler $L^{1}$ \\ ${ }^{1}$ Hochschule Niederrhein University of Applied Sciences, Faculty of Textile and Clothing Technology, Webschulstr, 31, D-41065 Mönchengladbach, Germany \\ ${ }^{2}$ Hochschule Niederrhein - University of Applied Sciences, Reinarzstraße, Krefeld, Germany
}

\begin{abstract}
Design attraction and design codes stands in relationship to function and strategy concepts in business cases of fashion as well as in automotive design. At the same time we are living in a design dominated world, which gets new inspirations by changing production processes from the fourth industrial revolution. Industry 4.0, that will transform design, operation, service, and manufacture of products. Generating design as "form follows function", with the requirement, like Dieter Rams said, "less design as possible" shows the timeless reasonable fact of classic style with focussing the end of natural sources. The demand on the beauty in design will never end. But what does "Beauteousness" means in design in the year 2020? How to generate new or timeless beauty in design? How to implement consumers demand for a wider variety of increasingly customized products.

The earlier definition of beauteousness during the renaissance time specified the term "beauteousness" in relationship to proportion, which had been measured with length in combination with the development of creating central perspective in art, to focus a harmonious balance of creative elements. Architects and theorists like Leon Batista Alberti defined a well proportion in balance, a harmony of elements to generate an ideal icon of beauty. During the 20 s century architects like Sullivan and the Bauhaus school taught the beauty in design as forms related to timeless combinations of geometric forms. The modern times opened the possibility to get new impetus of the beauty in design, when ugly design gets attraction: Umberto Eco asked about the beauty in ugly phenomena with the help of his book "on Ugliness", which inspired the fashion scene.

Now, during the $21^{\text {st }}$ century we have to consider that different parameters constructing beauty in design: sustainable requirements, bionic parameters and generated fashion are some examples. Beside the artistic and philosophical definition of beauteousness, the industrial process is creating beauty full forms: digital generating with special software allows to define new beauty full forms new beauty full codes in product design. And beside this, the generated design creates new functions. Today we know, that only the combination of thinking and doing, in analogue with digital processes will fashioning the future in all design disciplines.
\end{abstract}

Keywords: Beauteousness; Analogue and digital processing; Digital drawing; Industry 4.0; Fashion/engineering; Automotive/design; Sustainability; No waste; Beauty of functions; Aesthetic value; Bionic design; Generating fashion

\section{Introduction}

\section{Beauty full design inspired by bionic facts generating new design in automotive design}

The question of beauty in design is a question of perspective. In general the question about, what "Beauteousness" means stands in relationship to the term "beauty" as a conventional one used in art and architecture until today. The beauty is defined by the artist and scientist of art, by the philosophers and architects during the renaissance time, for example by Leon Batista Alberti (1404-1472) as a measurement of proportion of creative elements. The beauty has to find a balance in relevance to geometrics forms, length and laws to create the right central aimed perspective [1]. Later on the credo "form follows functions" by the architect Louis H. Sullivan (1856-1924), created the norm also for design objects, underlined by the time of 1920s and the school of the German Bauhaus (1919-1933), which is influencing design cultures around the world until today.

Now, in the $21^{\text {st }}$ century we have different cultural codes in design, product languages, which are demonstrating high formal aesthetical offers of artefacts, which are oriented at the credo of the designer Dieter Rams: "less design as possible" [2].
Beside these formal beauty of artefacts, we are going back to look at the beauty in nature. The beauty in form and functions, described the natural scientist and humanist Ernst Haeckel (1834-1919) in beautiful artificial forms of the see, like spin less animals of oceans shows us: the dependency of function and form, the power of creating their aesthetic result in generating and shaping beautiful, timeless and sustainable nature facts [3].

The scientist and humanist Haeckel, reconstructed the meaning of "beauteousness", focused on fascinating forms of spin less animals of the ocean. Their functions has been underlined not only by the structure of the body, but by the material, which build the body (like the studies of the Alfred Wegner Institute Germany proofed during

*Corresponding author: Wachs ME, Hochschule Niederrhein University of Applied Sciences, Faculty of Textile and Clothing Technology, Webschulstr, Monchengladbach, Germany, Tel: +4921518220; E-mail: Marina.wachs@hs-niederrhein.de

Received November 01, 2016; Accepted November 16, 2016; Published November 19, 2016

Citation: Wachs ME, Bendt E, Kreuziger M, Brinkmann T, Dornbusch L, et al (2016) The Beauty in Design - Aesthetics and Functions Caused by Combining Analogue with Digital Processing - Case Studies of Fashion Engineering and Automotive Design. Ind Eng Manage 5: 200. doi:10.4172/2169-0316.1000200

Copyright: ( 2016 Wachs ME, et al. This is an open-access article distributed under the terms of the Creative Commons Attribution License, which permits unrestricted use, distribution, and reproduction in any medium, provided the original author and source are credited. 
Citation: Wachs ME, Bendt E, Kreuziger M, Brinkmann T, Dornbusch L, et al. (2016) The Beauty in Design - Aesthetics and Functions Caused by Combining Analogue with Digital Processing - Case Studies of Fashion Engineering and Automotive Design. Ind Eng Manage 5: 200. doi:10.4172/2169-0316.1000200

Page 2 of 5

the 1990s). The Master thesis of Lucienne Dornbusch was inspired by the spin less animals: Frosted Nudibranch, Rose Lace Coral, Mosaic Pom-Pom - Spineless nature facts, art \& automotive inspiring future design \& textile material solutions“. This thesis combines inspirations of nature, art and fashion to create a new automotive design concept. In this case bionic parameters are the most important aspects for the product language and as well for the beauty full functions of innovative design: Three design products for concept cars named Frosense, Vacoral and Textacle had been target of this work. Invertebrates are the main source of inspiration and add a great value to the transmission from natural concepts to technology. The beauty in nature (in the oceans) gets attraction, but formed a natural structure in relationship to function. To transfer the essence of bionic parameters to automotive interior design shows the benefit in trans disciplinary design, for the acceptance of new functions in design and of a new beauty full product language (Figures 1-3).

\section{Analogue and digital "design doing" to create new design qualities in textile car concepts}

In focussing the benefit of new technological production processes, like 3D-printing for everybody, the co-designing in fab lab's and at home, the discussions began to rethink the qualities in design. Also the young design generation demanded to proof their design style, the so called "duktus" - the own unique handmade style in design. The result about high quality of design was generated by combining processes in sketching by hand and by modifying with digital programs, like photoshop or illustrator of the adobe creative suite, to come to an

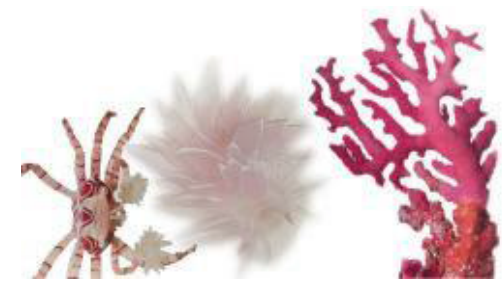

Figure 1: Spinless animals.
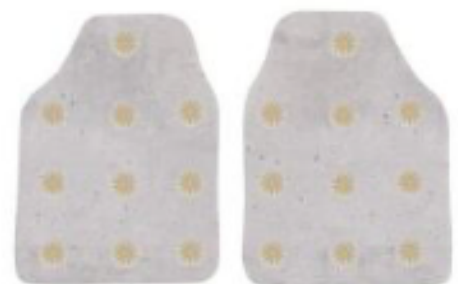

Figure 2: Design Lucienne Dornbusch: floor carpet with cleaning function

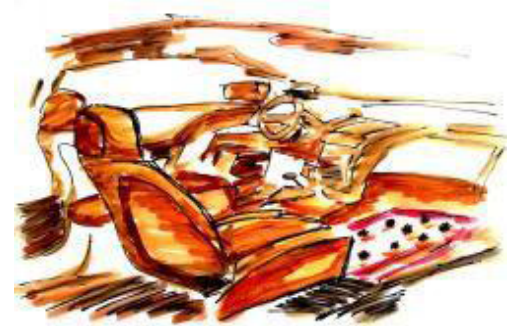

Figure 3: Design Lucienne Dornbusch automotive interior design, 2016. end in the computer added design process (CAD). The consequence of generating design by the discipline graphical design came to an end in manipulating software driven design. One example is shown by the thesis of Nadin Detering "Pixel vs. Brushstroke analogue \& digital media of art for a textile interior and exterior design: case study automotive design": Analogue and digital drawing techniques to bring out the own handwriting into design of interior design and automotive design as a concept car, represents the need to think about the human qualities in handcraft and about the limits of digital driven design qualities (Figures 4-9).

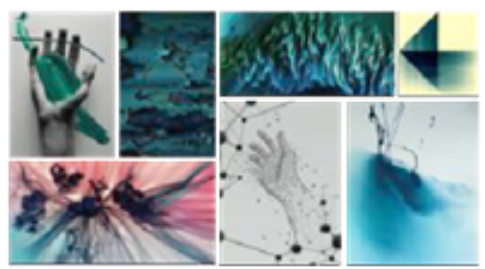

Figure 4: Mood.

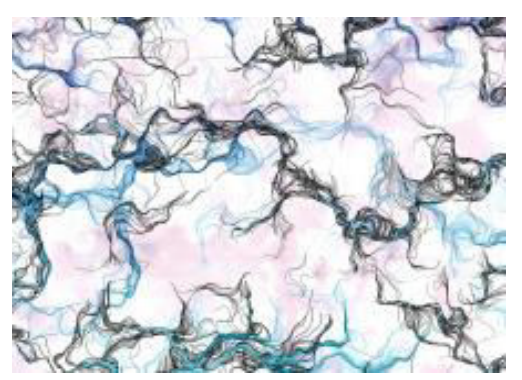

Figure 5: Generative Design.

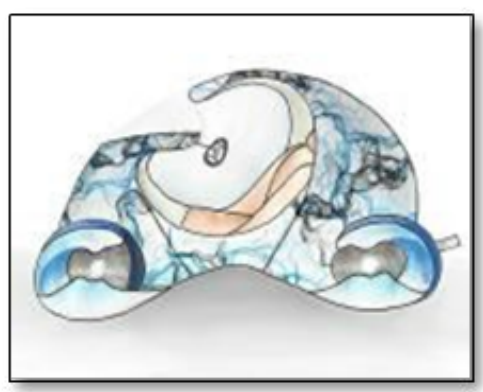

Figure 6: Automotive Vision: T-Wave.

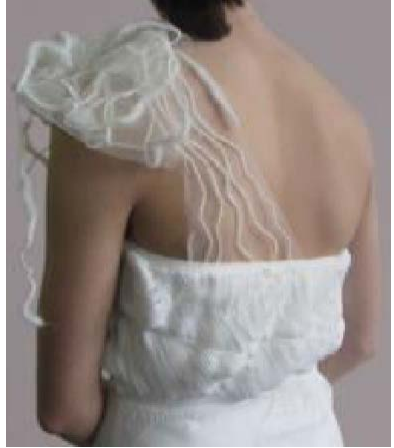

Figure 7: Dress with moving surface by MA student Sophia Krinner (pic 7+8: E. Bendt) 
Citation: Wachs ME, Bendt E, Kreuziger M, Brinkmann T, Dornbusch L, et al. (2016) The Beauty in Design - Aesthetics and Functions Caused by Combining Analogue with Digital Processing - Case Studies of Fashion Engineering and Automotive Design. Ind Eng Manage 5: 200. doi:10.4172/2169-0316.1000200

Page 3 of 5

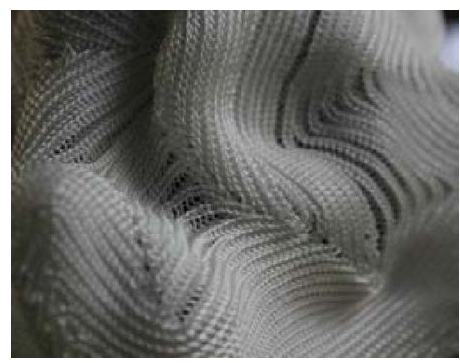

Figure 8: Dress with moving surface by MA student Sophia Krinner (pic 7+8: E. Bendt).

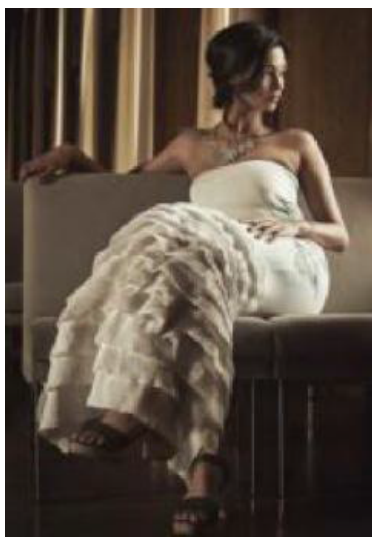

Figure 9: Dress with structures by ultrasonic welding by MA student Theresa Brinkmann (pic.: Tim Ilskens, 2016).

\section{No waste: The development of sustainable knitting clothes made from PLA fibers}

Like the studies of analogue and digital drawings are demonstrating, the new sustainability in 2020 is expressed by traditional resilient power of the human being. One very important act is the experience of experimental studies: The following research project, performed with a Master class on the subject "Experimental Knitting", points out the possibilities to create sustainable knitwear by using biodegradable high tenacity polyester on PLA basis (Diolen $150 \mathrm{BT}$ ), made from renewable resources, exclusively used in the automotive interior for safety belts and airbags. Lactic acid is a product of the fermentation process of corn starch. Therefore PLA is a thermo-plastic polymer derived $100 \%$ from plants. It is biodegradable and compostable under specific conditions.

The tasks of the project were to show that typical technical materials can also be used for clothing, to create multi-sustainable products and creative dealings with origination processes and development of something completely new by working with the properties of the material, like stiffness and shiny surface, and to implement it in a clothing concept.

To get access to the material the project started with knitting tests by hand on hand-driven and computerized (Stoll CMS 302 TC) flatknitting machines. Because of the harsh hand feel of this polyester type, it took some time until the results were satisfying. The students "played" with tension, knitting constructions, tested different finishing, treatments and combinations with wool and other materials. As expected: some very different surprising results and some very exciting outfits were generated. The most convincing - because most sustainable results -are those in $100 \%$ pure PLA yarns.
The project shows that, to overcome the limits of standard thinking in creative knitwear design, a confrontation with the material is essential. Samples of research results see below [4].

\section{Digital drawing}

Another way of using the aesthetic attributes of the sustainable material PLA in textile applications is to use 3D-printing directly on the textile substrate, in the patterns as a kind of digital drawing. In her master's thesis "A Common Thread the Aspect of Form in Fabric Construction and in Generative Manufacturing Processes" [5]. Mirja Kreuziger (Lutz) analyses different manufacturing processes in the textile industry and the individual design process of the respective technology. Focusing on generative manufacturing processes using thermoplastic PLA printed on textile surfaces Kreuziger (Lutz) demonstrates the reciprocal influence of form and process (Figures 10 and 11).

\section{Design spaces of textiles interfaces}

In interlinking the way of "design thinking" and "design doing" will give the inspiration for engineering programs for the next design generations. If we are working together in product design, fashion design, interior design and automotive design, we find smart solutions together in design in combining analogue and digital processes in higher level than lone some. To bring out sense of design and to overcome disciplines for the best solutions in engineering fields, will generate innovative design functions also about aesthetic function of design. The master's thesis of Linda Pfanzler proofs the interdisciplinary benefit of two disciplines (fashion and automotive interior design), - of two nations, cultural codes (Germany and South Korea) and double design qualities: "The Han Legacy: textile interface of fashion design and smart interior design in concepts cars" are connecting functions in design. At the same time an intercultural design dialogue had been initiated in analysing design codes of each nation. It is the new design quality of the $21^{\text {st }}$ century in interlinking design disciplines in using the method of design thinking. This new design quality, which is

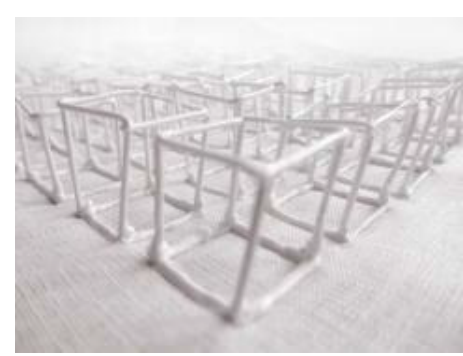

Figure 10: The line as a apatial element in 3-D drawings by M. Kreuziger

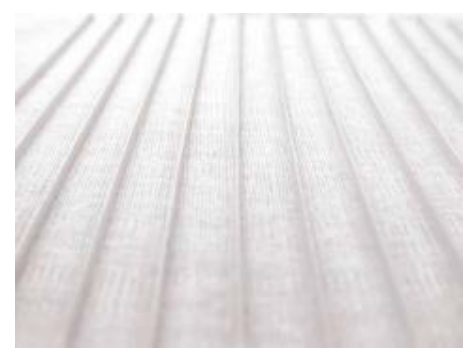

Figure 11: Imprinted lines shaped by the extrusion profile of the 3D-printers nozzle by Mirja Kreuziger. 
Citation: Wachs ME, Bendt E, Kreuziger M, Brinkmann T, Dornbusch L, et al. (2016) The Beauty in Design - Aesthetics and Functions Caused by Combining Analogue with Digital Processing - Case Studies of Fashion Engineering and Automotive Design. Ind Eng Manage 5: 200. doi:10.4172/2169-0316.1000200

focussing the network of function driven solutions will bring out a new beauteousness in design (Figures 12-14).

Another example showcases the innovative research work by Theresa Scholl about "Textile digital working spaces for the mobile IT-office in 2030". In cooperation with the international working interior architect Sylvia Leydecker, the database of offices and feel good working places are in focus to generate textiles connected spaces of co-working nomads for future generations. New scenarios of working, characterized by scientist based working, by low hierarchical structures of the team and new roles of the group, are initiating their own new patterns. In focussing the power of smart textiles and key characters of textile tools, function based systems are creating a working underlining space for feel good atmospheres. The connection of analogue and digital

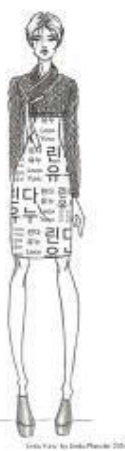

Figure 12: (By Linda Pfanzler): Design Fashion and Automotive Design: The Han Legacy-a textiles interface, 2016.

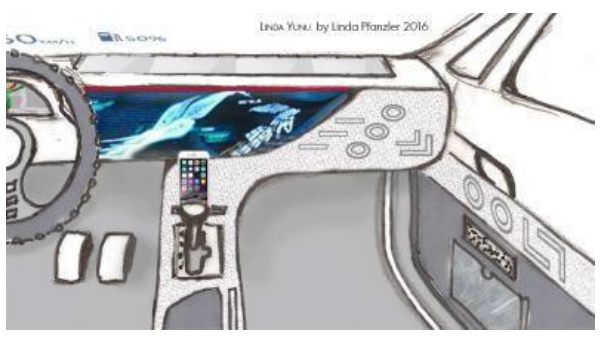

Figure 13: (By Linda Pfanzler): Design Fashion and Automotive Design: The Han Legacy-a textiles interface, 2016.

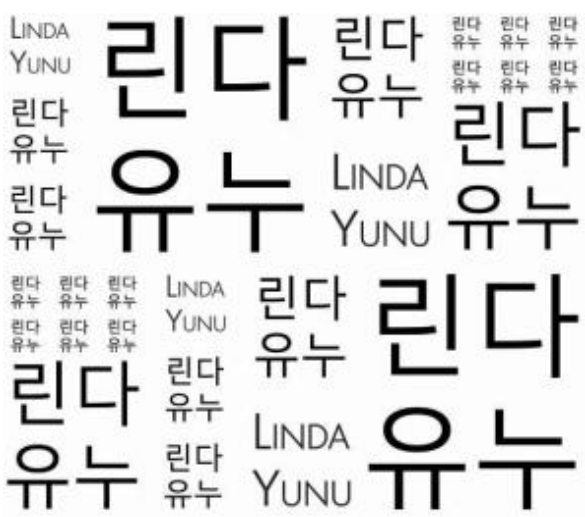

Figure 14: (By Linda Pfanzler): Design Fashion and Automotive Design The Han Legacy-a textiles interface, 2016.

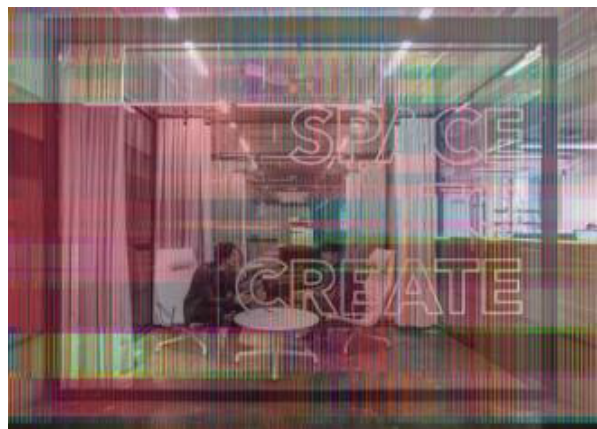

Figure 15: Textile interfaces and vision of textiles working spaces in 2030

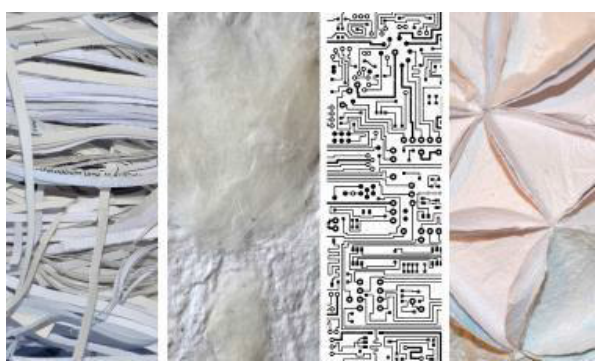

Figure 16: Textile interfaces and vision of textiles working spaces in 2030

textile design techniques drives the form, function and beauteousness of working spaces for tomorrow (Figures 15 and 16).

\section{Results}

To overcome condition driven design, in stressing analogue with digital design processes for a new beauteousness in design

The beauty in design today is represented by the engineering process of the fourth industrial revolution, and has consequence for the design qualities. In higher performance we could take benefit in interlinking and in overcoming spaces of different design disciplines: working together in rethinking the discipline, rethinking the solutions of the Industry 4.0 and in shaping new design qualities. For fashion and automotive design, for product and communication design qualities, we need analogue and digital interacting groups: Smart products integrated into intertwined digital and physical processes. The time has to come for interlinking engineering and fashion, textile and automotive design in a generated new aspect of "Beauteousness". The Beauty in design is generated by codes and product languages, which are defining forms, surfaces and, in a holistic way, aesthetic value of function and form. The possibilities in using digital tools, writing a software programme, within the CAD-process generates new forms, new patterns and encourage for rethinking about the qualities in design: to engage procedural representation and aesthetics [6].

\section{References}

1. Liessmann KP (2009) Schonheit, facultas, wuv, Austria

2. Ive J, Lovell S (2011) Dieter Rams: As little design as possible, Phaidon, USA.

3. Haeckel E (2005) Haeckel: Art Forms from the Ocean: The Radiolarian Prints of Ernst Haeckel, Prestel, Germany.

4. Bendt E (2016) No Waste: The development of sustainable knitting clothes made from PLA fibers, Fiber Society 2016 Fall Meeting and Technical Conference, Ithaca, USA. 
Citation: Wachs ME, Bendt E, Kreuziger M, Brinkmann T, Dornbusch L, et al. (2016) The Beauty in Design - Aesthetics and Functions Caused by Combining Analogue with Digital Processing - Case Studies of Fashion Engineering and Automotive Design. Ind Eng Manage 5: 200. doi:10.4172/2169-0316.1000200

Page 5 of 5

5. Lutz MA (2015) Nach Strich und Faden - Der Aspekt Form in der textilen Flachenbildung und in generativen Fertigungsverfahren, Hochschule Niederrhein University of Applied Sciences, Germany.
6. Reas C (2010) Form + Code in Design, Art, and Architecture, Princeton Architectural Press, p. 176. 